\title{
Studies on the Lingual Dorsal Epithelium of the Gunea Pig by Scanning Electron Microscopy
}

\author{
By \\ Shin-ichi IWASAKI and Ken MIYATA \\ Department of Oral Anatomy, Nippon Dental University, \\ 1-8, Hamaura-cho, Niigata 951, Japan \\ -Received for Publication, October 11, 1984
}

Key Words: Guinea pig, Tongue, Epithelium, Microridge, Scanning electron microscopy

Summary: Scanning electron microscopic observations were performed to investigate the structure of the lingual papillae and the ultrastructure of the real surface of lingual dorsal epithelial cells in guinea pigs.

Filiform papillae were distributed over the entire dorsal surface of the tongue except for the narrow radix zone. Fungiform papillae were scattered among these filiform paillae. In the posterior area of the fore-tongue, many coronal papillae, whose shape was different from both the filiform and fungiform papillae, were distributed.

Higher magnification of the lingual dorsal epithelium revealed that prominent microridges and distinctive cell marginal thickening occurred widely in the basal area of the filiform papillae, inter-papillar area and lingual radix area. On the epithelial surface of the upper part of the filiform papillae, only fine pits and hollows were found. Microridges forming network and parallel patterns were widely distributed on the coronal papillar surface.

Various types of papillae, such as filiform, fungiform, foliata and circumvallata papillae, are located on the lingual dorsal surface of mammals. Scanning electron microscopic studies of lingual papillae in mammals have been performed in rats (Švejda und Skach, 1971; Yoshioka and Muto, 1976; Kessel and Kardon, 1979; Iwasaki et al., 1984a), mongolian gerbils (Iwasaki et al., 1984b), musk shrews (Iwasaki et al., 1983), bats (Kobayashi and Shimamura, 1982) and cows (Steflik et al., 1983). In rats, mongolian gerbils and bats, various types of filiform papillae were found to be distributed on each definite area of the lingual dorsal surface. In musk shrews, filiform papillae were transformed gradually from the apex to the posterior body. One of the aims of the present study was to examine whether or not the distribution pattern of filiform papillae in the guinea pig was the same as that in other rodents.

It has recently become possible to observe the intact cell surface by scanning electron microscopy under better conditions than formerly, due to improvements in the method used for removing extracellular material from the dorsal surface of the tongue (Iwasaki et al., 1983, 1984a, b). In the present study, scanning electron microscopy was also employed to investigate the ultrastructure of the real surface 
of the lingual dorsal epithelial cells in connection with keratinization.

\section{Materials and Methods}

Tongues from seven male guinea pigs at 5 to 10 weeks old were used. The animals were perfused from the heart with Karnovsky fixative containing glutaraldehyde and paraformaldehyde under Nembutal anesthesia. The tongues were then removed and refixed with the same fixative. After rinsing in $0.1 \mathrm{M}$ cacodylate buffer, the materials were post-fixed in phosphatebuffered $1 \%$ osmium tetroxide solution at $37^{\circ} \mathrm{C}$ for 2 hours, and treated with $8 \mathrm{~N}$ hydrogen chloride at $60^{\circ} \mathrm{C}$ for 30 minutes to remove extracellularly attached material by acid hydrolysis. This was followed by dehydration, critical point drying and gold-ion sputtering. Finally, the specimens were observed under a scanning electron microscope (Hitachi S-500).

\section{Observations}

The tongue of the guinea pig is relatively long with a round tip, and has an intermolar eminence at about the posterior $1 / 3$ (Fig. 1). Filiform papillae were distributed over almost the entire dorsal surface of the tongue except for the narrow zone of the lingual radix. In the apex, branched filiform papillae were distributed densely on the dorsal surface and sparsely on the lateral surface (Figs. 2 and 3). All of these papillae were bent slightly backwards, and each divided from the basal part into about three thin branches. Of these three branches, the central one was somewhat larger than the other two (Fig. 4). The end of each branch was pointed. Each filiform papilla was $70-100 \mu \mathrm{m}$ in basal diameter and $100-150 \mu \mathrm{m}$ in height. Fungiform papillae were scattered among the filiform papillae over the dorsal and lateral surfaces (Figs.
3 and 4). In the anterior half of the lingual body, the filiform papillae were larger than those in the lingual apex. The central branch was markedly thicker and longer than the lateral two in these papillae, and the tip of the central branch was round (Fig. 5). Similar filiform papillae were also distributed in the anterior and latero-posterior areas of the intermolar eminence. The filiform papillae were bent forwards only in this area (Fig. 6). The upper halves of these papillae tapered off to a point. The lateral branches of each papilla were very short and thin. Each papilla was 100-200 $\mu \mathrm{m}$ in basal diameter and $300-400 \mu \mathrm{m}$ in height. The inter-papillar spaces were relatively wide (Fig. 7). In the rear-middle area of the eminence, many coronal papillae, whose shape was different from the conical filiform and fungiform papillae, were densely distributed (Fig. 6). These papillae had a club-shaped projection located in the center of these papillae, and the projection was surrounded by a narrow groove. Further, petal-like epithelia were piled up outside this groove (Fig. 8). Each papilla was $70-$ $150 \mu \mathrm{m}$ in basal diameter and 100-200 $\mu \mathrm{m}$ in height.

Higher magnification of the basal epithelial surface of a papilla in the apex revealed a network of clear microridges. The margin of this epithelial cell was thickened (Fig. 9). In the middle region of a branch of the same papilla, microridges of the epithelial cell surface were also observed, but they were not very distinct (Fig. 10). On the upper surface of the same branch, there were only fine pits and hollows (Fig. 11). The filiform papillae located on the anterior half of the lingual body had almost the same fine structure as those on the apex, and clear microridges were distributed mainly on the basal surface of the papillae. The conical filiform papillae in the intermolar eminence had a fine micro- 
ridge-like structure over the whole surface from base to apex (Fig. 12). Microridges forming network and parallel patterns were widely distributed on the coronal papillar surface of the intermolar eminence. Thickening of the epithelial cell margin was also distinct in this papilla (Fig. 13). Microridges and cell marginal thickening were widely noted over the surface of the lingual radix (Fig. 14). The cells in the cut surface of the basal area of the filiform papilla were very flat, and had widely spread microridges on both the exterior and interior sides (Fig. 15).

\section{Discussion}

In the present study on the guinea pig, the conical filiform papillae underwent a gradual change from the apex to the posterior area, i.e. from a branched type in the anterior area to a non-branched type in the posterior area. This change in papillar form was somewhat different from other rodents such as rats (Švejda und Skach, 1971; Yoshioka and Muto, 1976; Iwasaki et al., 1984a) and mongolian gerbils (Iwasaki et al., 1984b). However, the coronal papillae on the rear surface are thought to be a variation of the filiform papillae since their distribution frequency and pattern were almost the same as those of the conical filiform papillae and the area of location of these papillae was restricted to the posterior dorsal body. It can be considered therefore that the distribution pattern of the filiform papillae in the guinea pig is essentially the same as in other rodents, rats and mongolian gerbils, and also in bats, and further, is different from that in the musk shrew. More detailed observations are required to clarify the relationship between the distribution pattern of filiform papillae and the taxonomical grouping of mammals.

It has been reported recently that microridges are widely distributed on the oral epithelial surface in relation to keratinization (Cleaton-Jones and Fleisch, 1973; McMillan, 1974, 1979; Cleaton-Jones, 1975; Appleton and Heaney, 1977). However, there have been few reports concerning the microridges on the lingual dorsal surface because of the difficulty in observing the real surface of the epithelial cells due to the covering mucus, especially on the inter-papillar surface. In the present study, the same method as had been successfully used in rats, mongolian gerbils and musk shrews was adopted. With this method, the epithelial cell surface could be observed under better conditions not only as regards the papillar surface but also the inter-papillar one. Furthermore, there were no very distinct differences in structure of the microridges between acidtreated specimens and untreated specimens. The results obtained in this study showed that microridges are relatively clearly apparent on the basal surface of the papilla and the inter-papillar one, but do not have such a distinct outline as in the musk shrew. Indeed, the outline of the microridges in rodents is generally unclear in comparison with that in the musk shrew. However, further observations must be performed in more mammalian species from the taxonomical viewpoint in order to resolve this problem.

Fahrenbach and Knutson (1975) presumed that microridges represented an adaptation of the structure of the epithelium to friction, while Sperry and Wassersug (1976) indicated that microridges might play a role in the retention of mucus and appeared to facilitate the spread of mucus. The results of the present and previously reported studies (Iwasaki et al., 1983, $1984 a$, b) have revealed that the filiform papillar surface, on which keratinization is histologically more pronounced than that on other areas (Cane and Spearman. 1969; Farbman, 1970; Baratz and Farbman. 
1975), does not have clear microridges in rodents and musk shrews. Thus, microridges do not necessarily occur in the adaptation to friction because it may be stronger at the surface of filiform papillae. It is suggested from the above facts that microridges may appear in the course of the keratinization of epithelial cells to fasten neighbouring cells together, and that these structures may disappear when the keratinization has increased beyond a certain degree. As pointed out by Sperry and Wassersug, it is also thought to be true that in the lingual dorsal surface microridges may play a role in retaining mucus on the cell surface and facilitating the spread of mucus on the epithelial cell surface. That is to say, it is assumed that both filiform papillae and microridges may function as supporting structures for fooduptake, mastication and swallowing.

\section{References}

1) Appleton, J. and Heaney, T. G.: A scanning electron microscope study of the surface feature of porcine oral mucosa. J. Periodont. Res., 12: 430-435, 1977.

2) Baratz, R. S. and Farbman, A. I.: Morphogenesis of rat lingual filiform papillae. Am. J. Anat., 143: 283-302, 1975.

3) Cane, A. K. and Spearman, R. I. C.: The keratinized epithelium of the house-mouse (Mus musculus) tongue: its structure and histochemistry. Archs. Oral Biol., 14: 829$841,1969$.

4) Cleaton-Jones, P. and Fleisch, L.: A comparative study of the surface of keratinized and non-keratinized oral epithelia. J. Periodont. Res., 8: 366-370, 1973.

5) Cleaton-Jones, P.: Surface characteristics of cells from different layers of keratinized and non-keratinized oral epithelia. J. Periodont. Res., 10: 79-87, 1975.

6) Fahrenbach, W. H. and Knutson, D. D.: Surface adaptation of the vertebrate epidermis to friction. J. Invest. Dermat., 65: 39-44, 1975.
7) Farbman, A. I.: The dual pattern of keratinization in filiform papillae on rat tongue. $J$. Anat., 106: 233-242, 1970.

8) Iwasaki, S., Sakata, K., Mori, H., Ueno, M. and Kobayashi, K.: Ultrastructure of the lingual dorsal surface in Suncus murinus (Linne). Jpn. J. Oral Biol., 25: 471-480, 1983 (Japanese with English summary).

9) Iwasaki, S., Miyata, K., Mori, H., Sakta, K. and Kobayashi, K.: Fine structure of the lingual dorsal surface in rats. Acta Anat. Nippon., 59: 18-27, 1984a (Japanese with English summary).

10) Iwasaki, S., Sakata, K., Miyata, K., Mori, H. and Kobayashi, K.: Fine structure of the lingual dorsal epithelium of mongolian gerbil. Jpn. J. Oral Biol., 26 : 292-296, 1984 b.

11) Kessel, R. G. and Kardon, R. H.: Tissue and organ; a text-atlas of scanning electron microscopy. W. H. Freeman and Co., San Francisco, 1979.

12) Kobayashi, S. and Shimamura, A.: Comparative anatomical observations of the tongue of the Japanese long-fingered bats, Miniopterus schreibersi fuliginosus. Okajimas Fol. Anat. Jpn., 58: 923-932, 1982.

13) McMillan, M. D.: A scanning electron microscopic study of keratinized epithelium of the hard palate of the rat. Archs. Oral Biol., 19: 225-229, 1974.

14) McMillan, M. D.: The surface structure of the completely and incompletely orthokeratinized oral epithelium in the rat; a light, scanning and transmission electron microscope study. Am. J. Anat., 156: 337 $352,1979$.

15) Sperry, D. G. and Wassersug, R. J.: A proposed function for microridges on epithelial cells. Anat. Rec., 185: 253-258, 1976.

16) Steflik, D. E., Singh, B. B., Mckinney, R. V. Jr. and Boshell, J. L.: Correlated TEM, SEM, and histological observations of filiform papillae of the cow tongue. Acta Anat., 117: 21-30, 1983.

17) Švejda, J. und Škach, M.: Die Zunge der Ratte im Raster-Elektronenmikroskop (Stereoscan). Z. Mikrosk.-anat. Forsch., 84: 101-116, 1971.

18) Yoshioka, I. and Muto, H.: Surface structures of the tongue, palate and buccal mucosa of the rat (scanning electron microscopic studies on the oral mucosa, 3). Okajimas Fol. Anat. Jpn., 52: 297-312, 1976. 


\section{PLATES}




\section{Explanation of Figures \\ Plate I}

Fig. 1. Macroscopic view of the lingual dorsal surface of a guinea pig. Arrow: Intermolar eminence. $\times 1.8$.

Fig. 2. Scanning electron microscopic photograph of the dorsal apex. $\times 30$.

Fig. 3. Lateral view of the apex. Fungiform papillae $(\mathrm{Fu})$ are scattered among the filiform papillae. $\times 120$. 

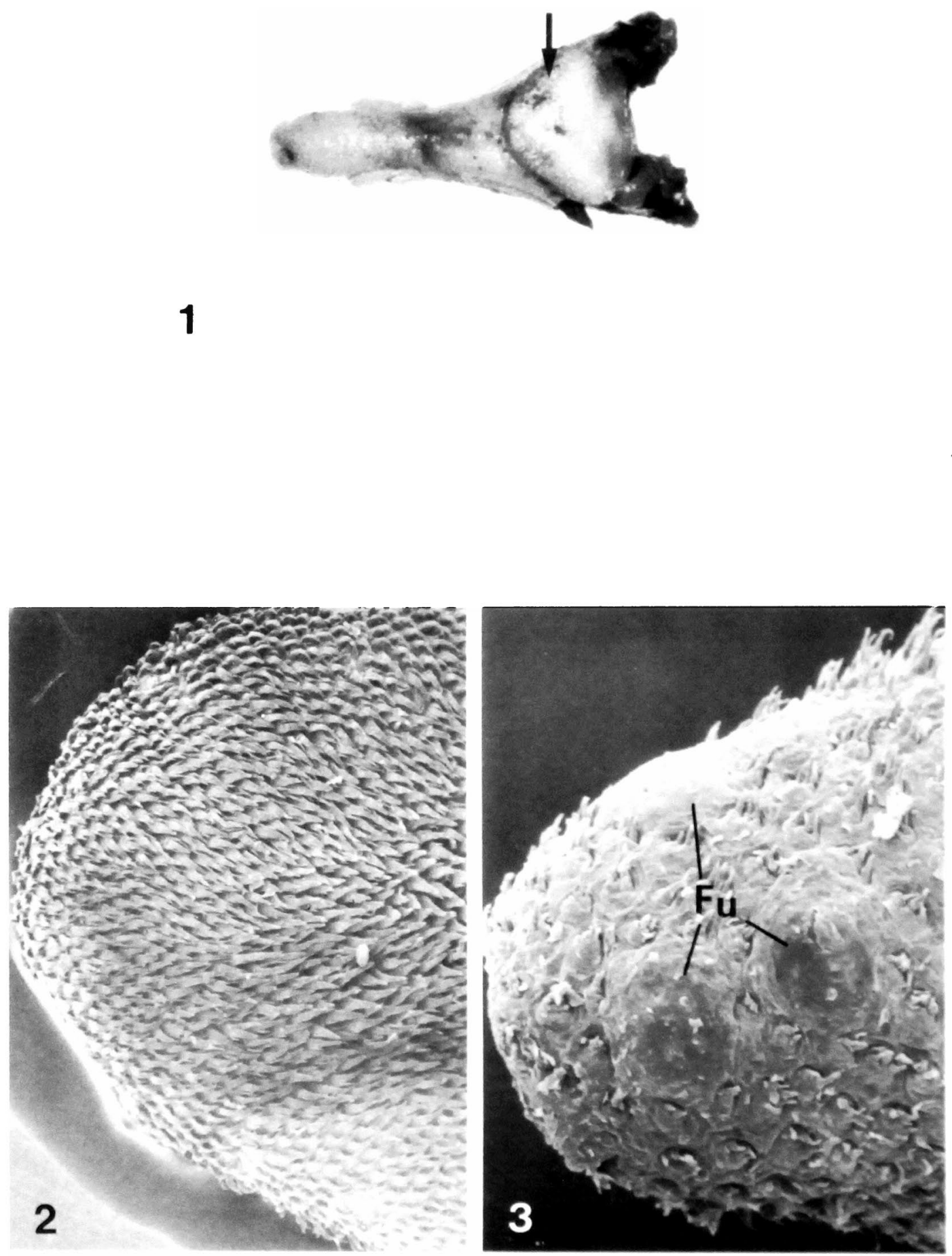


\section{Plate II}

Fig. 4. Lower magnification of the apical dorsal surface. Filiform papillae (Fi) are divided into three thin branches from their base. Fu: Fungiform papilla. $\times 120$.

Fig. 5. Filiform papillae in the anterior half of the body. The central branch (thick arrow) is markedly thicker and longer than the two side ones (thin arrows). $\mathrm{X}+00$.

Fig. 6. Lower magnification of the surface of the intermolar eminence. Fi: Conical-shaped filiform papillae with a pointed apex. $\mathrm{Cr}$ : Coronal papillae. $\times 26$.

Fig. 7. Conical-shaped filiform papillae on the anterior surface of the intermolar eminence. The lateral branches (arrows) of the papillae are short and thin. $\times 320$. 

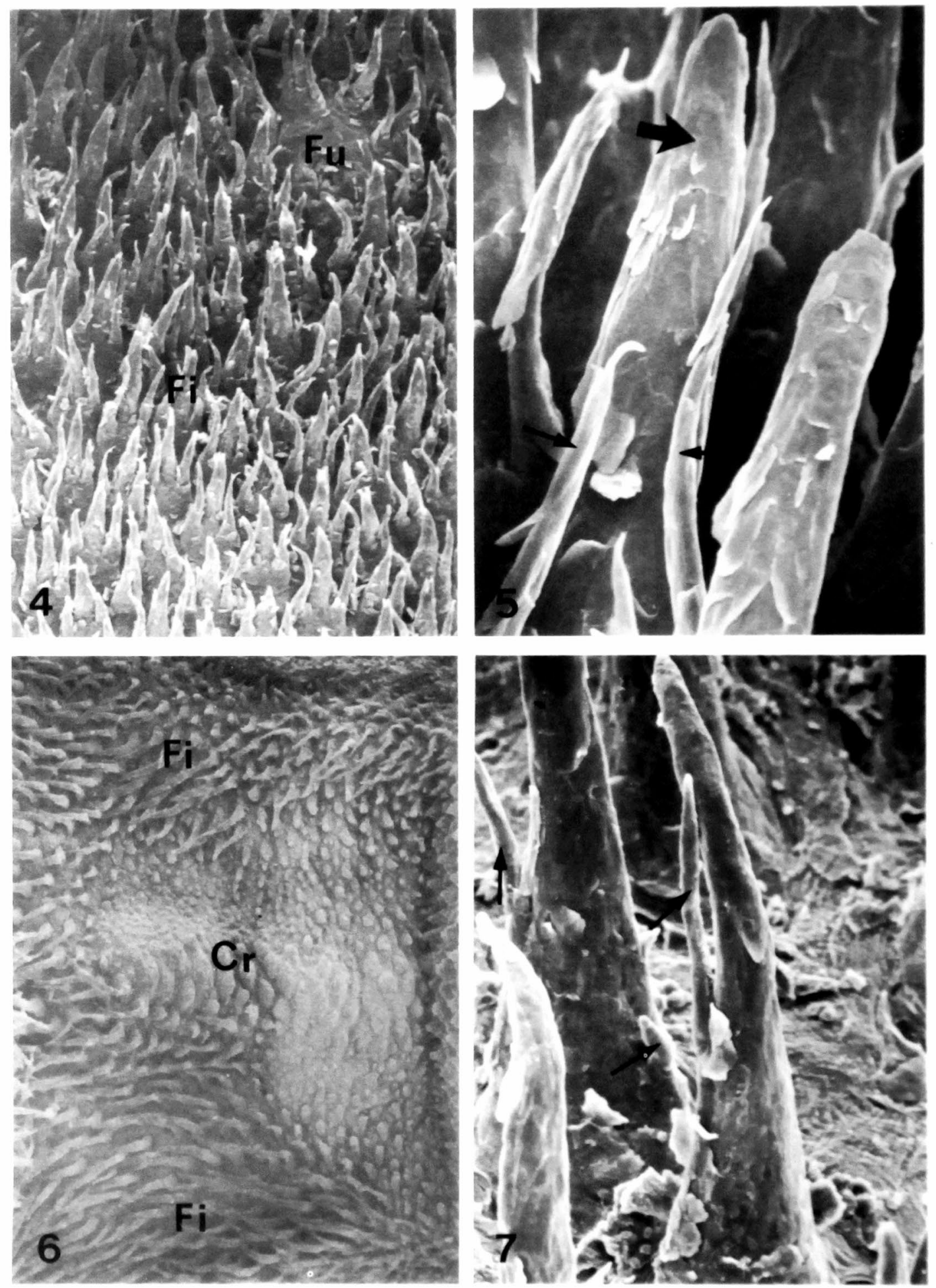


\section{Plate III}

Fig. 8. Coronal papilla on the rear-middle surface of the eminence. A club-shaped projection (thin arrow) is located in the center of this papilla, and the projection is surrounded by a narrow groove (thin arrow). Petal-like epithelial cells (curved arrows) are piled up outside of this groove. $\times 1200$.

Fig. 9. Higher magnification of the basal epithelial surface of a papilla in the apex. Note the clear microridges with a network pattern and the marginal thickening of the cells (arrows). $\times 3200$.

Fig. 10. Higher magnification of the middle epithelial surface of the same papilla as in Fig. 9. Microridges are also recongnized, but are not so distinct. $\times 3200$.

Fig. 11. Higher magnification of the upper epithelial surface of the same papilla as in Fig. 9. There are only fine pits and hollows. $\times 3200$. 

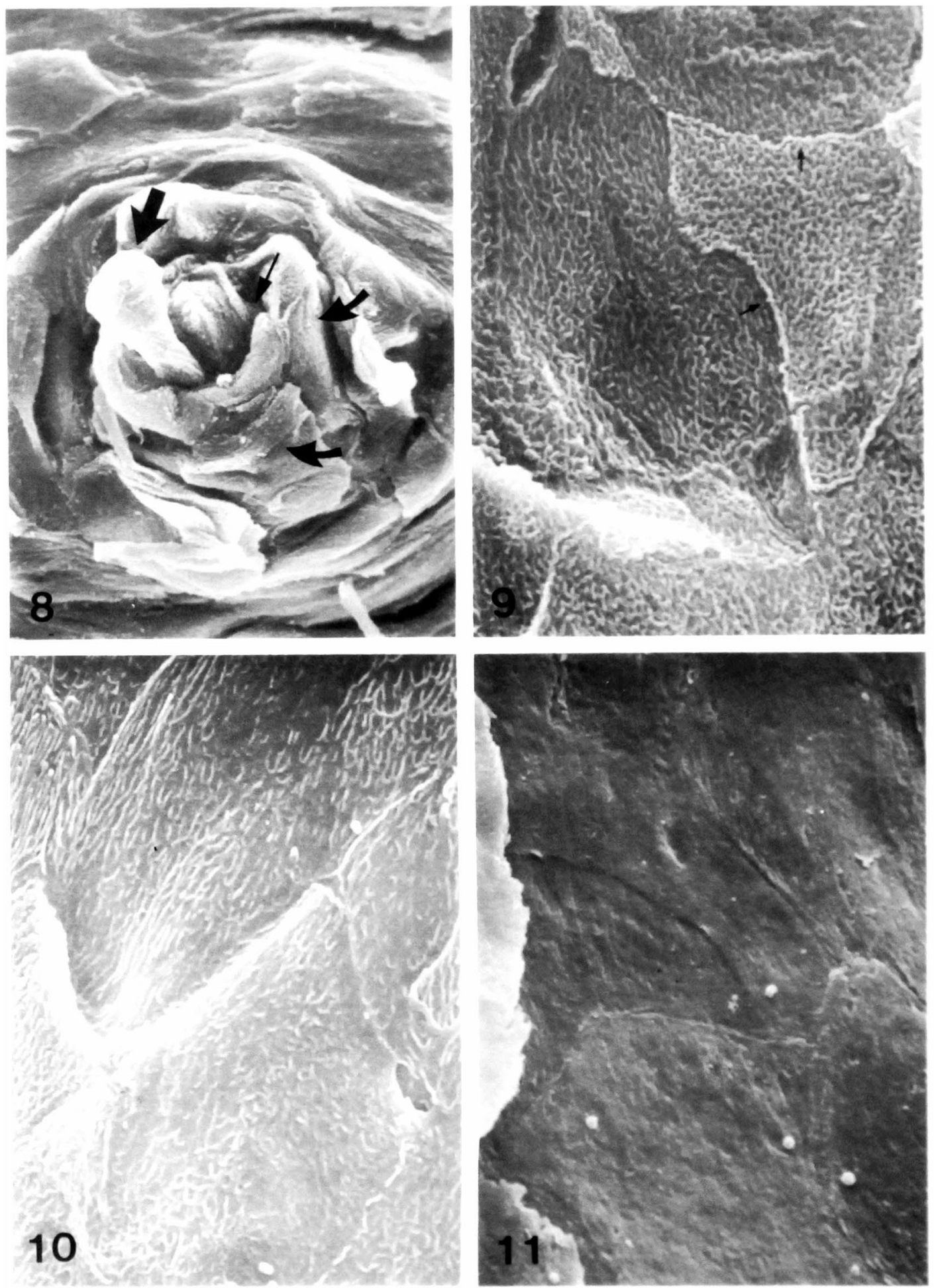


\section{Plate IV}

Fig. 12. Higher magnification of the upper surface of a conical filiform papilla on the intermolar eminence. Note the fine microridge-like structures. $\times 3200$.

Fig. 13. Higher magnification of the coronal papillar surface of the intermolar eminence. Both microridges with a network (thin arrows) or parallel (thick arrows) pattern and thickening of the cell margins (curved arrows) are clearly apparent. $\times 5200$.

Fig. 14. Higher magnification of the radix. Microridges and cell marginal thickening (arrows) are widely observed. $\times 1400$.

Fig. 15. Cut surface of the basal area of a filiform papilla. Microridges are widely spread on both the exterior (thick arrow) and interior (thin arrow) sides of flat cells. $\times 3200$. 

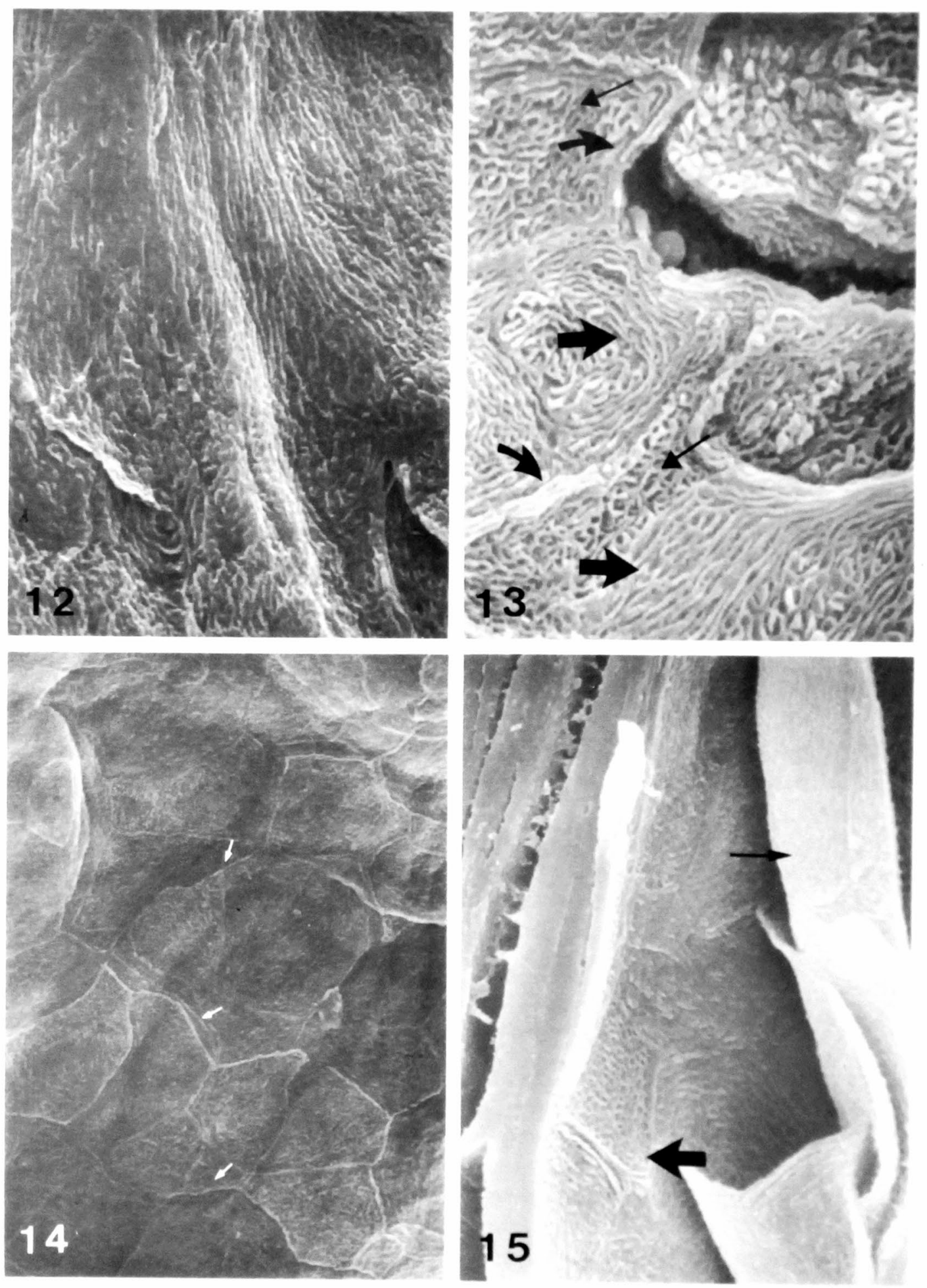